\title{
Vidas em canções e outras notas sobre cultura autobiográfica
}

\section{Lives In Songs And A Few Notes On Autobiographical Culture}

\author{
Ricardo Santhiago ${ }^{1}$ \\ rsanthiagoc@gmail.com
}

Resumo

Neste ensaio, trato das imbricações de canções de cunho autobiográfico e da cultura autobiográfica do nosso tempo. Proponho que consideremos aquelas canções que têm como assunto a personalidade ou determinados episódios da vida de seu intérprete como uma declaração sobre si que se soma a muitas outras. Ao longo do artigo, percorro canções que descrevem ritos de passagem geográficos e simbólicos; canções que visam captar a essência de uma personagem; canções que, em conjunto, apontam para a coincidência de percepções acerca de um mesmo indivíduo.

Palavras-chave: Canção popular; Cultura autobiográfica; Memória

\begin{abstract}
In this paper I address the imbrication between autobiographical songs and the present-day autobiographical culture. I suggest that we should consider those songs, whose subjects are the personality or episodes in life of their singers, as self statements to be added to a number of other declarations. Throughout the essay, I go through songs that describe geographic and symbolic rites of passage; songs that aim to catch somebody's "essence;" songs that altogether indicate the coincidence between two or more perceptions about a third subject.
\end{abstract}

Keyworks: Brazilian popular songs; Autobiographical culture; Memory

1 Pós-doutorando na Universidade Federal Fluminense 
Artigos

\section{Memórias da meia noite}

Uma canção não para de tocar no rádio:

The story of my life

I take her home

I drive all night

To keep her warm

And time is frozen

The story of my life

I give her hope

I spend her love

Until she's broke inside

The story of my life

Vozes masculinas se entrecruzam, mas não sei reconhecê-las. Suponho que se trate de uma boy band de sucesso, e logo descubro que estou certo: é o One Direction, um quinteto de garotos britânicos muito jovens. Eu já tinha ouvido falar deles. Caroline, minha irmã, e Kamila, minha prima, têm 12 e 13 anos, respectivamente - as duas gostam da banda e já haviam me apresentado seus animados sucessos anteriores. $\mathrm{O}$ Google me ajuda a saber os nomes das músicas de que me lembro: What Makes You Beautiful, Best Song Ever... Nenhuma havia me interessado mais que sua duração.

Caroline e eu temos estado muito juntos. Minha mãe, ela, Fernando e eu temos saído muito de carro e sempre ligamos o rádio, zapeando entre meia dúzia de estações que abrangem quase todos os gostos: duas de música popular brasileira, duas de música pop, duas demais de muzak. Nenhuma deixa de confirmar a "regressão da audição", é claro, mas à exceção das rádios de conteúdo nacional todas se curvam a The Story of My Life. Nos Estados Unidos, a canção chegou ao primeiro lugar da Billboard, na categoria de canções pop na faixa adulta, e ao sexto lugar na categoria geral. Ganhou discos de ouro na Alemanha, na Itália, no Reino Unido e na Suécia. Na Austrália, no Canadá, nos Estados Unidos, no Japão, no México, na Noruega e na Nova Zelândia, recebeu discos de platina. Blaine e Kurt, personagens de apelo da Glee, deram nova roupagem à música na sexta temporada da série.

Acho mais interessante a versão da minha irmã, no banco de trás:

The story of my liiiiiiiife

The story of my liiiiiiiife

The story of

The story of

The story of my life

Ficamos algo estarrecidos com a convicção com a qual ela canta esses versos, apropriando-se deles (porque sabe seu significado), aludindo apaixonadamente à sua "história de sua vida" - com 12 anos de idade! Dos membros do grupo, seria possível dizer o mesmo: Harry nasceu em 1994; Liam, Nial e Zain são de 1993; Louis, o mais velho de todos, é de 1991. Não há dúvidas de que todos tenham muitas histórias para contar e inúmeras experiências marcantes. Mas não parece um pouco precoce esse mergulho tão intenso na "história da minha vida", da qual essa canção (e sua recepção) é uma dentre tantas manifestações visíveis? Não. Tampouco que ela esteja inserida num álbum chamado Midnight Memories, que tem se saído tão bem. Eles estão mergulhados em uma cultura autobiográfica; como nós, "vivendo autobiograficamente".

\section{Autobiografias vocais}

É possível que One Direction, como outras bandas do mesmo perfil, esteja fadada ao esquecimento (não importa que seu verbete na Wikipedia informe que eles tenham sido comparados aos Beatles). De qual- 
quer forma, Story of My Life será lembrada: lhes ajudará, assim como a muitos adolescentes de agora, a rememorar seu passado, no futuro. Eduardo Coutinho provou o suspeitado em seu fabuloso filme As canções: que estas mobilizam lembranças, atuam como disparadores da memória, informando a elaboração de narrativas em presença sobre recordações associadas a elas, a canções que são várias... A memória não tem preconceitos nem se inibe diante daquilo que obstruiríamos como sendo cultura de massa, popularesca, simplória, homogeneizada, sensacionalista, impositiva... Os mecanismos que entrecruzam canções e lembranças não têm barreiras culturais, de gosto; não se regem por faixas etárias; não atingem apenas a faixa intelectualizada com seus repertórios tão diferenciados. Há uma cultura autobiográfica inculcada em todos nós.

Fala-se em um "retorno do biográfico", em uma "cultura da memória, em um "boom memorialístico". Fala-se de uma era de superexposição, de celebrização vazia, de consagração imediata. No meio disso, parece haver uma região que é atravessada e que atravessa esses dois feixes de influência: essa cultura autobiográfica que nem sempre implica uma exposição de detalhes íntimos nem uma entrega sôfrega à rememoração. É só uma espécie de valorização e de exercício das histórias pessoais, convidadas a estar em toda parte. Pegue o controle remoto e assista ao canal a cabo GNT: no Chegadas e partidas, histórias de vida sobre viagens e reencontro; no Viver com fé, histórias de superação inspiradoras; no Chuva de arrož, relatos sobre casamentos e relações; em Morar, a relação das pessoas com a casa, a cidade... Ufa!

É Paul John Eakin quem sugere que estamos "vivendo autobiograficamente" - no título sugestivo de um de seus livros. "Contamos histórias sobre nós mesmos todos os dias. Às vezes conseguimos fazer com que outras pessoas as escutem, mas mesmo quando não conseguimos, este processo de autonarração está constantemente se desenrolando em nossa cabeça", ele começa (2008, p. 1), para depois demonstrar que a inclinação autobiográfica se dá em diferentes níveis, chegando a casos de indivíduos que relatam uma espécie de "compulsão" pela narração de si (p. 152). Como Eakin, outros desenvolveram argumentos correlatos. Jerome Bruner (2014) indagou sobre o papel das histórias na vida, como na literatura, e no direito... Brian Boyd (2009) sugeriu que nosso apego pelas histórias é uma característica adquirida dentro do processo evolutivo: elas teriam contribuído para o desenvolvimento da criatividade, da coesão social. Parece que chegamos a um ponto em que é intolerável e indesejável resistir a essas histórias ubíquas, onipresentes: em nosso cotidiano, nos livros, nas mídias, no ensino e na pesquisa... Como a canção seria insensível a essa disposição para as histórias pessoais?

Estamos acostumados a ouvir, sobre certas canções, variações da frase: "Essa música foi feita para mim" - irrepreensível cimentação social de várias identidades individuais construídas narrativamente. A pouco lembrada cantora Diana, que iniciou sua carreira durante a Jovem Guarda, gravou em 1973 uma livre versão que ela mesma fez para My Reason, do cantor grego Demis Roussos. Metalinguística, a nova letra dizia: "Eu sinto uma saudade muito grande / quando lembro dos momentos / em que ouvíamos a música // A canção falava de um casal que se amava / e pra nós ela dizia tanta coisa / a música (...) // ao mundo inteiro / eu gostaria tanto de dizer / que eu não posso mais / ouvir a música"’2.

As canções podem, mesmo, ser o texto privilegiado para representar histórias de nossas vidas: sejam nossas grandes histórias biográficas, sejam nossos recortes de experiências. Eu poderia ter alguma dificuldade em sintetizar a história da minha vida em uma ou duas canções, mas provavelmente me sentiria satisfeito selecionando talvez 20 delas para representar seus grandes períodos. Por outro lado, seria capaz de me lembrar com detalhes de um período em particular se fosse auxiliado pela escuta: pode ser uma canção que me toca, pode ser uma canção que o rádio tocava, pode ser um jingle, pode ser algo completamente inusitado. Quem tiver o hábito de ler blogs pessoais vai encontrar seus autores, em algum momento, listando as "músicas de suas vidas" e justificando detalhadamente o elenco. Em um desses blogs, chamado Toilet Feminino, sua autora Juliane fala de Compasso, de Angela Ro Ro:

O que ME define? INTENSIDADE. É 80 ou 800. Gosto do frio na barriga, de chorar de gargalhar, de amar e me doar, de transformar o segundo em eternidade. Que cada dia seja transformado em um capítulo essencial e relevante na história de minha vida. Que não seja em vão. O que a música tem a ver? Tudo. Ela é uma definição perfeita de minha pessoa... e fala por si...

2 A música da minha vida (My reason). Stelios Vavlianos, Charalampe Chalkitis, Helen Banks. Versão: Diana. Diana, LP Uma Vez Mais, CBS, 1973. 
Artigos

A conexão com a canção, às vezes, é mais palpável. Lembro-me do episódio que a compositora e cantora Tata Fernandes me contou na memorável entrevista de história oral que gravamos há alguns anos. Ela relatou o que ocorrera décadas antes em uma viagem ao Rio de Janeiro, quando voltava de uma pizzaria com um casal de amigos:

Ele estava dirigindo, a mulher dele estava do lado, e eu e a Cris íamos atrás, quase cochilando... Eu estava sentada com a perna no bando e o rosto no vidro, praticamente dormindo.

Comecei a ouvir, vinda do rádio, uma música que eu não gostava...

mas se um dia eu chegar muito estranho

deixa essa água no corpo lembrar nosso banho

mas se um dia eu chegar muito louco

deixa essa noite saber que um dia foi pouco

cuida bem de mim

então misture tudo dentro de nós

porque ninguém vai dormir nosso sonho, sonho...

Esse "cuida bem de mim" ficou ressoando tanto na minha cabeça que saí da posição em que eu estava. Percebi que a casa já estava chegando, peguei minha bolsa e já fui me arrumando para sair. Sorte a minha! Fechei os olhos e, quando abri, o carro estava capotado. Capotou três vezes e o lugar onde eu estava ficou completamente amassado. Se eu não tivesse ouvido aquela música chata, mas que salvou minha vida e fez com que eu acordasse, eu estaria no mínimo em uma cadeira de rodas. (Santhiago, 2009, p. 89)

Uma música pode, então, tornar-se memorável porque salva nossas vidas. Ou pode ser memória construída, representação das nossas vidas - estamos falando daquilo que poderíamos despretensiosamente denominar de canções autobiográficas. E, sendo autobiográficas, têm como referente a identidade ou a história de vida de quem as interpreta: os cantores. Alcançam sua grandeza como variações vocais de um gênero eminentemente escrito. Compostas ou não por eles, são obras em primeira pessoa. Seu conteúdo, aliás, não precisa necessariamente ter sido criado em função da biografia ou das qualidades do intérprete. Mais importam, como vamos ver, as relações estabelecidas entre tal conteúdo e tal biografia no momento da atualização da canção; mais importam os artifícios de interpretação e performance que permitem aos ouvintes apreciar a canção como "contação" de si.

\section{“Meu 'it' revela"}

Comecemos por um primeiro terreno de autoconstruções que urdem uma espécie de recorte biográfico, enfatizando um aspecto ou período da vida do narrador/cantor. Desenham, quase, ritos de passagens; delineiam um movimento entre antes e agora, entre passado e presente, encobrindo esse movimento com uma atmosfera idealizada, marcada pelo mágico, desconhecido ou doloroso. Em todos os casos, por um episódio marcante que caracteriza efetivamente uma guinada na trajetória de vida do personagem retratado. Carmen Miranda, pioneira em tantos sentidos, esteve na dianteira também ao cronicalizar sua vida pessoal e profissional na música que cantava. Disseram que voltei americanizada, de Vicente Paiva e Luiz Peixoto, é a mais significativa da parcela de seu repertório onde se inserem também Diz que tem, de Vicente Paiva e Anibel Cruz, entre outras. Teria sido esse mais um caminho, entre muitos outros, aberto por Carmen para cantoras brasileiras?

Por vezes, o teor autobiográfico da canção não é incutido intencionalmente no momento de sua composição, mas adquirido quando de sua interpretação. O compositor sul-mato-grossense Geraldo Espíndola, dessa conhecida família musical sul-mato-grossense, criou em 1972 seu blues Deixei meu matão. Foi sua obra de estreia, e a que o tornou conhecido como uma referência musical na região. Mais de dez anos depois, sua irmã Tetê Espíndola gravou a canção. Ao observarmos sua letra e inseri-la no contexto da trajetória de Tetê, poderíamos imaginar que a composição teria sido não apenas composta para ela naquele momento, mas inspirada em seu novo contexto de vida: 
Quando eu vim

Ninguém sorria pra mim

Quando deixei aquilo lá

E vim pra cá

Não chorei não

Graças a Deus

Deixei meu matão

Vou sentir saudade da velha amizade

Dos bares e campos de lá

Ai mamãe não quero chorar

Todos os amigos do meu coração

E vai te catar

Em meados dos anos 1980, Deixei meu matão soava como a criação feita sob medida para representar a guinada na carreira de Tetê Espíndola, que, pelo desejo de seus novos produtores e empresários, abandonaria decisivamente sua verve experimentalista e regionalista para se tornar uma cantora pop de massa. Não à toa, a gravadora investiu comercialmente na música: carro chefe do LP Gaiola, a composição de Geraldo foi divulgada e prensada como um "disco mix" promocional, no qual a imagem da cantora em um ambiente controlado (o estúdio), em oposição a um espaço ingovernável (a natureza), era fartamente explorada, com quatro fotografias solo na capa, e outras cinco fotografias ao lado de músicos e artistas na contracapa.

Ao interpretar a canção com sua voz única, Tetê parecia narrar sua própria conversão de menina brejeira para estrela midiática, conversão que teve seu ponto alto com a vitória de Escrito nas estrelas no Festival dos Festivais, da TV Globo, em 1985. Deixei meu matão parecia aludir à sua rápida deglutição por uma cultura midiática cuja escassez de sorrisos é já demarcada no tempo passado; e o tempo do matão lhe é ainda anterior: aquele em que Tetê gravava o disco experimental Pássaros na Garganta (1982), posando para a fotografia de capa hipoteticamente nua em uma cachoeira, ou o de Tetê e o Lírio Selvagem (1978), emblema da música ecológica e coletivizante do Centro Oeste brasileiro, cuja capa estampava Tetê e seus irmãos usando collants com estampas de animais selvagens.

O tempo presente, da canção, é o do disco Gaiola (1986), em que uma montagem coloca a cantora à frente de prédios; o nome do álbum cintila sobre um deles, como um neon; na contracapa há uma arara azul contra a mesma paisagem. É uma capa que tem muito a dizer. Tetê usa uma blusa vistosa, na cor pink, de aparência metalizada, em alto contraste com o fundo, que garante: ela está na grande cidade. Mais que isso, está colocada em um importante centro financeiro: o skyline é o da avenida Brigadeiro Faria Lima. À direita, na capa, enxergamos um B e um S invertido no topo dos prédios: letreiros dos bancos BCN e Safra, provavelmente, bem próximos da esquina com a avenida Rebouças. A contracapa equilibra o ônus comercial com a presença da arara azul - só que está na mesma cidade, muito mais enegrecida, em meio às luzes que se apagam. Apoia-se em lugar algum. É protagonista de um deslocamento kitsch, além de ecologicamente impróprio.

Mas a memória cultural parece ser infalível. A foto de capa consiste em uma sobreposição de imagens que visa simular um movimento (a que está em segundo plano, propositalmente embaçada, desbotada). É pouco certo que se trate de uma única fotografia, registrada com o obturador em velocidade lenta, já que nesse caso haveria uma gradação maior entre as imagens principais. O efeito buscado, entretanto, é esse: a foto constrói, com Deixei meu matão, a isotopia da guinada. O observador deve compreender o estado anterior da artista, em seu espectro: sua cabeça abaixada, seus olhos provavelmente fechados, a ausência de sorriso, sugerem a melancolia do tempo em que não havia sorrisos. O efeito do obturador lento simula a captura de uma mudança na fisionomia, na linguagem corporal, nas emoções expressas. A personagem teria levado as mãos ao peito, olhado energeticamente para a frente e aberto um grande sorriso.

Em todos os casos, vê-se que a performance extraordinária de Tetê - seja seu corpo e sua voz, seja a performance mediatizada que compulsoriamente lhes traduz - é indispensável para a compreensão das teias 


\section{Artigos}

de significado de sua obra. No entanto, seria realmente possível que as emoções se alterassem tão profundamente no decorrer do funcionamento do obturador?
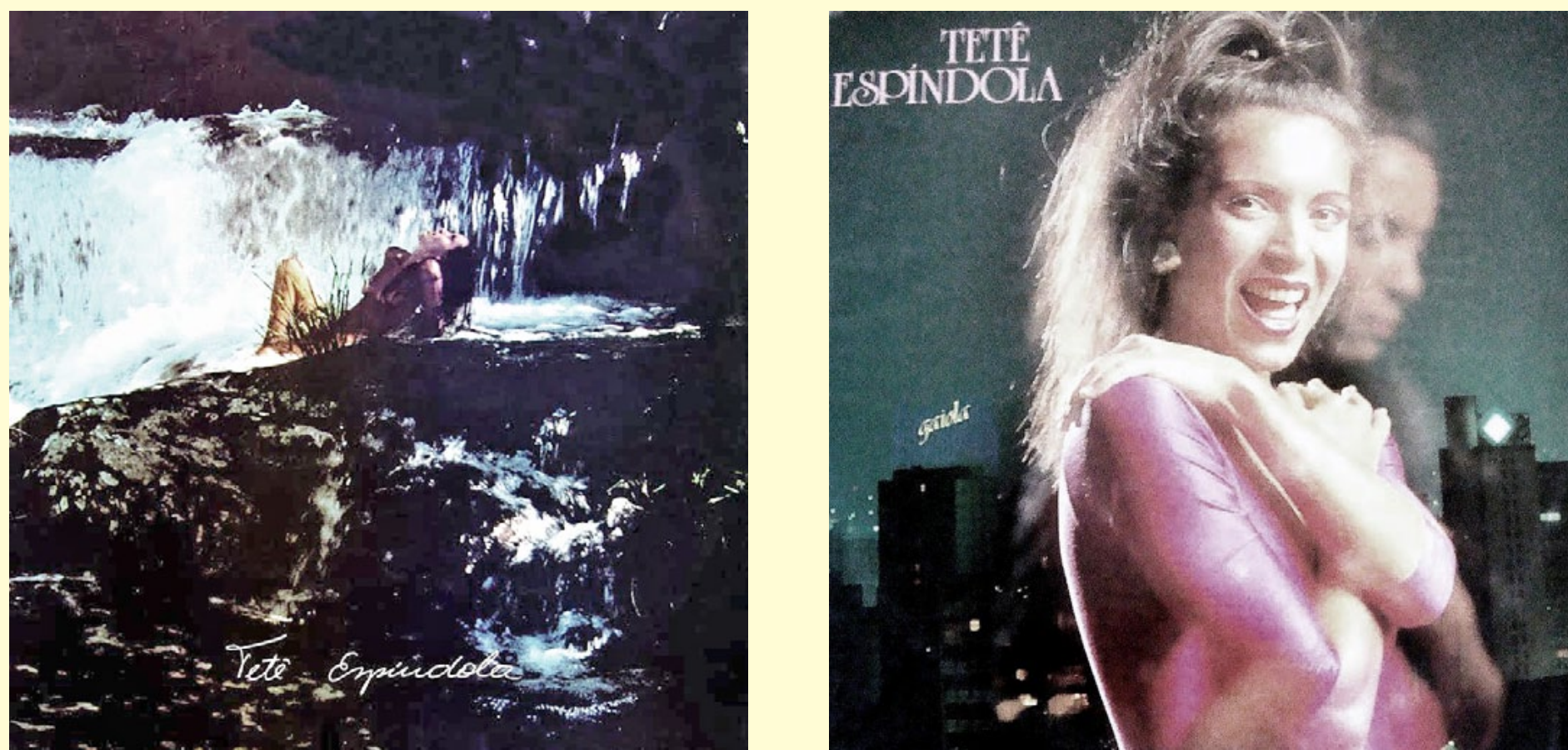

Pássaros na garganta (1982) e Gaiola (1986), de Tetê Espíndola: as capas de seus LPs salientam sua transição pessoal e profissional do "matão" que ela deixou para a "cidade" em que se consagrou

Deixei meu matão é também um rito de passagem geográfico, em que Tetê se narra, no presente, a partir de um local desconhecido, mas pressuposto: algum dos grandes centros fonográficos do país (o Rio de Janeiro ou São Paulo), nunca o Centro-Oeste, de modo que se descreve também um deslocamento concreto. Em Saia Azul também é assim. A música de Dante Ozzetti e a letra de Chico César ofereceram à cantora Ceumar, no disco Achou! (2006), uma possibilidade de aludir ao seu próprio passado:

Quando eu vim de Minas

Comprei uma saia azul

Azul-Diamantina tipo furta-cor

Dessas que não tinha igual a outra e outra igual

Dessas que combinam com blusa de flor

Beijei meu pai

Dei benção à mãe

Olhei pra trás

Vi Minas dando adeus

Quem tem uma saia azul

E leva pra onde for

Encontra em outro lugar

Minas por lá

Blusa de flor

Quando uso a saia azul

E saio a passear

É um contentamento

Que eu sinto leve o vento me levar

Se a construção cantada por Tetê Espíndola adquire seu efeito de verdade essencialmente em função da performance da artista, Saia Azul apoia-se fundamentalmente no binômio clássico da canção: música e letra.

A obra convida a uma atmosfera menos palpável, menos figurativa, mas oferece elementos de refe- 
rência suficientes: a origem geográfica de Ceumar e sua migração. Remete ainda aos laços familiares, tema importante na poética da artista, nas composições de sua lavra. A letra poderia ser entendida como um relato da migração de Ceumar, nascida na cidade mineira de Itanhandu, para São Paulo - destino de muitos outros que compartilham seu ofício. Ela toca melhor em dois pontos centrais para a trajetória da cantora.

O primeiro deles diz respeito a versos como "leva pra onde for" e "deixo o vento me levar": tópico frequente na vida da cantora é a ausência de planos de longo prazo que se apresentem como inalteráveis. Após deixar sua cidade natal, a artista passou por Belo Horizonte, Itajubá e Salvador antes de se estabelecer em São Paulo, onde consolidou carreira. Depois de estabelecida, não hesitou em arriscar o prestigioso lugar conquistado e, por amor, trocou o Brasil pela Holanda, em 2009, confirmando o lirismo de Chico César para a música de Dante Ozzetti. O mesmo ocorre no que diz respeito ao segundo aspecto, que consiste na persistência e na valorização das origens: sua mãe, seu pai e Minas Gerais.

Em suas composições autorais, Ceumar referendou a letra dos colegas. "Ela foi a primeira voz / desde a primeira vez / que o som se fez", escreveu em Mãe. Em Rio Verde, parceria com Gildes Bezerra, diz: "Rio de vida / verde que corre / Lágrima da Mantiqueira / Corre por mim nas Gerais / Cresce por Minas Gerais". Seu influxo libertário se manifestou em Meu mundo, com Tata Fernandes: "Meu mundo só tem começo / Meus desejos não têm fim". Em Dança, com Yaniel Matos: "Solte seus pés, vamos voar / Que a vida pode nos levar, nos levar".

Se Saia Azul exprime elementos fundamentais de Ceumar, ou pelo menos da figura pública que ela nos apresenta, muito se deve ao seu letrista, poeta, Chico César. E é oportuno lembrar que ele não compôs um rito de passagem apenas para sua amiga e colega de Itanhandu - mas fez um sobre si mesmo, uma de suas mais dramáticas e pungentes canções, cuja coincidência entre autor e intérprete intensifica a percepção da canção como uma autoconstrução. Trata-se de Desejo e necessidade, que se inicia pelos versos:

Ai estou nas malhas de estranha cidade

Mas uma parte de mim

eu diria que a metade

Ficou lá onde saí

ou seja eu me reparti

Desejo e necessidade

Se Deixei meu matão e Saia azul repousam sobre o plano da individualidade, da experiência autobiográfica, Desejo e necessidade vai além - interpretação com grande chance de ser feita por aqueles que conhecem melhor seu autor, extremamente politizado, engajado, com compromissos ideológicos e partidários manifestados publicamente. A singularidade de sua experiência pode ser, via Desejo e necessidade, inserida no contexto mais amplo da história do Brasil contemporâneo, marcada por migrações internas e seus estigmas, choques, dilemas. O autobiográfico, aqui, converte-se em testemunhal; o pessoal, em político, como esbraveja o chavão que os grandes compositores evitam. Mas esse deslocamento é assunto para outra hora.

\section{“Cai a folha, quem sopra meu nome?"}

Passemos agora a um segundo plantel de canções de cunho autobiográfico, que vão além de fragmentos de experiência: são obras que buscam "capturar" a "essência" de um indivíduo, traduzindo-a em música e letra de maneira desejavelmente indisputável, a tal ponto que esse mesmo indivíduo aceite interpretá-la assumindo-a publicamente como uma construção de si em forma de canção. Trata-se de uma espécie de projeção autobiográfica, que só funciona porque no ato de escuta existe um alheamento da figura do compositor: a interação primordial se dá entre obra, cantor e ouvinte. O exemplo modelar dessa vertente de canções no Brasil é Meu nome é Gal, de Roberto e Erasmo Carlos, feita a pedido de Guilherme Araújo, então empresário de Gal Costa, que esta gravou em seu terceiro álbum, de 1969, oportunamente intitulado Gal-um dos mais significativos do início de sua carreira. É uma canção tão popular que sequer nos damos conta de quão interessante ela seria, do ponto de vista analítico, formulando 
Artigos

questões para os estudos autobiográficos. Como outras do mesmo tipo, traria inúmeras problematizações às formulações e tipologias sobre o gênero autobiográfico. ${ }^{3}$

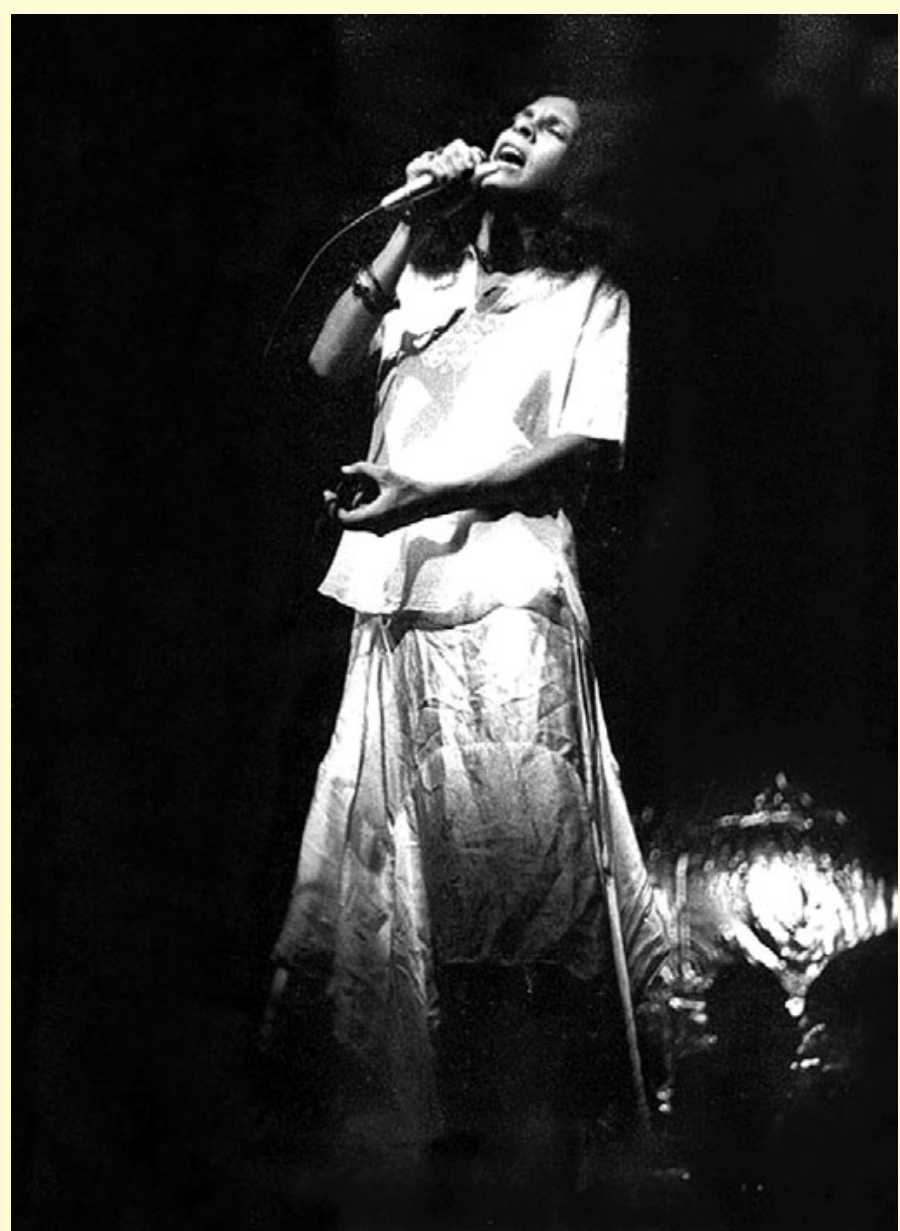

Gal Costa, em 1970, no show Deixa Sangrar. Arquivo pessoal Gal Costa. Disponível em: http://www.galcosta.com.br/sec_ fotos_view.php?id=244

Tanto no caso anterior - dos "recortes biográficos" em forma de canção, tais como os ritos de passagem - quanto nos casos de representações do eu mais abrangentes, o problema da autoria está posto. Aqui ele se radicaliza, uma vez que situações de apresentação pessoal como aquelas simuladas em canções como Мeu nome é Gal implicam uma situação comunicativa e um diálogo. A distinção entre o sujeito que percebe e o sujeito que enuncia - para pensarmos de acordo com a definição de Genette (1990) - deve ser apagada, e uma das maneiras de fazer isso é reforçar o eu da canção, torná-lo cada vez mais próximo do referencial: o sujeito percebido.

Trata-se de uma convenção inusitada. Da perspectiva do letrista, a canção que se tornará autobiográfica ao ser interpretada por outro não é resultado de um trabalho de memória, mas de construção de um personagem - não ficcional, porém, mas que corresponda à percepção pública de alguém ou à sua suposta essência, desconhecida, que se quer revelar. Da perspectiva do retratado, interpretar essa canção implica concordar com o ponto de vista do outro sobre si, baseado em pressuposições. Implica uma aceitação de tal ordem que culmina em incumbir-se da tarefa de amplificar esse ponto de vista, de projetá-lo para um público massivo, geralmente muito mais amplo do que o de uma autobiografia escrita. Há, ora, sempre a possibilidade de renegar parcialmente essa concordância. Especialmente quando a canção é entendida como um discurso excessivamente egocêntrico, pode-se apelar convenientemente para o subterfúgio da autoria: "Não fui eu que compus...". Pois se aceitou cantá-la...

Meu nome é Gal, protótipo desta linhagem de canções, não deixou que sua personagem/intérprete fosse marcada pelo egocentrismo, por mais que entoasse repetidamente o nome "Gal" em seu antológico dueto/duelo com a guitarra na gravação original. O fato de que a canção falava a inquietações e anseios compartilhados por toda uma geração contribuiu para isso. A primeira camada de entendimento da canção foi e continua sendo a de uma apologia ao amor livre: o "desejo" de se "corresponder / com um capaz que seja o tal", sem restrições a "cultura", "altura", cor, "crença", "tradição" ou "defeito". Tanto quanto as posteriores A maçã, de Raul Seixas e Paulo Coelho, ou O seu amor, de Gilberto Gil, interpretada pelos Doces Bárbaros, Meu nome é Gal encoraja essa interpretação. Existe ainda um elemento na gravação que nos compele a perseverar no entendimento de que Gal dizia seu nome para quem quer que lhe oferecesse amor: a passagem do canto para a fala.

Após cantar os versos de Meu nome é Gal pela primeira vez, a cantora narra um pequeno discurso ampliando a apresentação que faz de si. Se havia dúvidas de que o conteúdo semântico das palavras cantadas não deveria ser atribuído a ela - seja por ser cantado, seja por ser composto por Roberto e Erasmo Carlos (para aqueles que relacionavam a figura dos compositores no momento da audição, o que é raro) -, essas dúvidas poderiam então ser dirimidas com o uso dessa estratégia que realça o efeito de verdade do discurso em primeira pessoa. Ninguém conta a sua vida cantando - a menos que de forma ensaiada, preparada, e em todo caso artificial. Contamos nossas vidas falando, assim como faz Gal Costa em sua intervenção:

3 Ver, para as mais conhecidas delas, Lejeune (2008). 
Meu nome é Gal, tenho 24 anos, nasci na Barra Avenida, Bahia. Todo dia eu sonho alguém pra mim. Acredito em Deus, gosto de baile, cinema. Admiro Caetano, Gil, Roberto, Erasmo, Macalé, Paulinho da Viola, Lenny, Rogério Sganzerla, Jorge Ben, Rogério Duprat, Waly, Dircinho, Nando, e o pessoal da pesada. E se um dia eu tiver alguém com bastante amor pra me dar, não precisa sobrenome, porque é o amor que faz o homem.

A trajetória e os costumes privados da cantora importavam tanto quanto o comportamento ressonante que ela encarnava. Para seu público, aquela mulher, com aquela religião, com aqueles ídolos e amigos, com aquelas preferências artísticas, interessava mais à medida que constituía um novo modelo de inserção social. Não apenas o amor livre - mas o amor (independente das amarras sociais do casamento, das atribuições formais, representadas pela marca do sobrenome) e a libertação (de expectativas e condicionamentos). A Gal traçada na canção falava de ideais libertários e reconhecia-se na Gal que interpretava a canção: com um visual arrojado, volumosos cabelos; com um comportamento vivamente desafiador contrastando com o ambiente repressor; com suas cores flexuosas sobre chapas cinzas. Obra, vida e contexto produzindo um resíduo impuro sob a forma de um fonograma inesquecível: repleto de ruídos e gritos, milhas distante seja do ideário bom-mocista da época, seja do horizonte bem comportado das cantoras da boa tradição da música popular brasileira.

Meu nome é Gal acompanhou Costa ao longo de toda a sua carreira. Um ano após ser gravada, deu nome a um documentário em curta metragem de Antonio Carlos Fontoura, coleção de imagens em movimento acompanhada pela interpretação de Meu nome é $G$ al e duas outras canções. ${ }^{4}$ Uma década depois de seu lançamento original, ainda tinha força suficiente para atrair a atenção do programa Fantástico para a confecção de um de seus clipes, sendo anunciada como "um duelo entre Gal Costa e a guitarra, um dos melhores momentos do show que já passou das 100 apresentações no Rio". ${ }^{5}$ A té hoje, Gal Costa fez pelo menos quatro registros oficiais da canção: em Gal (1969), Gal Tropical (1979), no programa Ensaio de 1994, lançado em DVD (2005), e em Gal Costa - Ao Vivo (2006). A música, além disso, foi incluída em diversas coletâneas da cantora, desde a Série de Autógrafos de Sucessos - Gal Costa, de 1973, à Gal Revisitada, feita pela gravadora Dubas 30 anos depois.

A eficácia de Meu nome é Gal era perceptível para a artista, para o público e para os colegas do meio musical. Quatro décadas depois de seu lançamento, mobilizou Waly Salomão na busca por um replay, com o chute a gol protagonizado por Cássia Eller. Segundo conta Beatriz Helena Ramos Amaral em seu livro Cássia Eller: Canção na voz no fogo (2002), o estopim para a ideia de Waly surgiu a partir de um elogio feito a Cássia pelo poeta e compositor Péricles Cavalcanti: "Eu queria ser você". O próprio Péricles identificou ali o mote para uma canção, que todavia não foi composta imediatamente. Quando Lan Lan, percussionista na banda de Cássia, falou a Waly sobre a originalidade do elogio, ele teria imediatamente vislumbrado a força de uma obra musical com a mesma energia vital e o mesmo mecanismo de identificação de Meu nome é Gal. Daí a insistência com Péricles Cavalcanti na finalização da obra.

O resultado foi Eu queria ser Cássia Eller, cujo poder comunicativo depende fortemente da capacidade do intérprete em alternar ou reter intenções, com nuances mínimas: com uma letra extensa e intrincada, o apelo da canção apoia-se sobre o refrão "e não há nenhuma outra hipótese / que eu não considere, mas / o que eu queria mesmo ser / é a Cássia Eller”. A lógica da canção está nos versos que precedem o refrão, em uma história contada pelo avesso - uma construção biográfica, por que não dizer, retorcida? É como se percebe nos versos primeiros:

Eu poderia ser um padre ou um dentista

Um arquiteto, um deputado ou jornalista

Eu poderia ser ator e me dar bem

Ser um poeta que escreve versos como ninguém

Eu poderia ser um general da banda

Uma modelo, um herói da propaganda

Eu poderia ser escravo do trabalho

Ser um banqueiro, um estilista do baralho

4 Meu nome é Gal. Dir.: Antonio Carlos Ferreira. Cor, 12 min. 1970.

5 Disponível em: http://globotv.globo.com/rede-globo/fantastico/v/gal-costa-canta-meu-nome-e-gal/1070837/. 
$\mathrm{Na}$ composição de Péricles, os tempos verbais não definem uma experiência passada, mas um projeto de vida construído no presente: são arroladas diversas possibilidades de escolha para a personagem que canta, mas a melhor delas é ser Cássia Eller. As várias opções, chances e expectativas são arremessadas de maneira aleatória, tão fortuita quanto os acontecimentos da vida. Elas são de muitos domínios da vida social: dos mais convencionais aos mais fortuitos. Opções que saciam o corpo ("um campeão de golfe / de luta-livre, de xadrez e do que quer que fosse"), a alma ("um monge no Nepal"), o intelecto ("um professor de escol", "um grande cineasta"), o ego ("um escritor da moda", "o rei do futebol”) - todas elas são descartadas na vereda de uma prioridade: "ser Cássia Eller".

A cantora, entretanto, não entoava os versos de Péricles no rasto de si mesma. Beatriz Helena Ramos Amaral relata no perfil biográfico de Cássia que ela não se sentia à vontade para cantá-la no show Veneno antimonotonia, não obstante a insistência de Waly:

sentindo que apresenta-la nos shows poderia representar pretensão, ou egolatria de sua parte, em razão da letra. Em alguns dos shows, deixou de cantá-la, por isso. Noutros, fez a inclusão. A peculiar habilidade do diretor Waly Salomão para a construção de situações cênicas e a razoável ascendência que já conquistara sobre Cássia acabaram por convencê-la. Convencionaram então que, no encerramento do show, quando voltasse ao palco para o tradicional "bis", a cantora diria ser a Cássia Rejane, que queria ser a Cássia Eller (Amaral, 2002, p. 118)

O destacamento entre a Cássia-intérprete e a Cássia-personagem foi o que permitiu à primeira, portanto, introduzir a obra em seu repertório. Em 1998, à Folha de S. Paulo, a artista disse, a respeito: "Só concordei quando saquei: era eu mesma querendo ser eu, aquela mulher que solta os bichos no palco. No dia a dia, não sou assim" (apud Amaral, 2002, p. 118-9). A canção cumpriu sua sina. Tornou-se um emblema da cantora, ainda que não um de seus maiores sucessos. Foi registrada em Veneno vivo, CD de 1998, e logo incluída em Millenium, coletânea de hits de Cássia lançada no ano seguinte, quando Péricles Cavalcanti também a gravou no autoral Baião Metafísico. Cantada por outras pessoas, o título adquire um significado algo literal: uma demonstração pública e musical de deferência. Recentemente, em Filipe Catto canta Cássia Eller, tem sido o primeiro lance do cantor nos palcos em que se apresenta.

Uma apropriação desse tipo teria menos chance de acontecer com uma outra construção biográfica bastante popular: Muito prazer, Zezéé, que Rita Lee e Roberto de Carvalho - compositores consagrados - escreveram para Zezé Motta - à época estrela em ascensão, a quem eles pouco conheciam. Zezé havia se celebrizado nacionalmente em virtude do filme Xica da Silva, de Carlos Diegues (de repercussão internacional, aliás) no final dos anos 1970. Com isso, teve a oportunidade de iniciar uma carreira paralela como cantora. Para seu primeiro LP solo, o produtor Guilherme Araújo convocou compositores a apresentarem suas obras. Rita Lee estava entre eles. Sem ter tido contato pessoal com sua futura intérprete, valeu-se de materiais autobiográficos para propor uma construção artística de um fractal biográfico possível. Como contou Zezé, posteriormente: "A Rita Lee, que não sabia nada de mim, leu minhas entrevistas e fez, com o Roberto de Carvalho, o Muito Prazer Zezée, que é a minha cara" (Murat, 2005, p. 61).

A desbravadora artista negra não apenas aceitou a rara cortesia - mas a incorporou de forma terminante em sua carreira. Os shows do LP foram intitulados Muito prazer - palavras que estiveram no encalço de Zezé ao longo de sua vida, dando inclusive título à sua autobiografia narrada e publicada na coleção Aplauso, em 2005. A música de Rita Lee e Roberto de Carvalho, bem como o LP em que ela está inserida, são considerados "clássicos" da carreira da cantora. Em 2012, ela foi convidada a apresentar um revival do mesmo no Teatro Municipal de São Paulo, durante a Virada Cultural, reinterpretando-o de maneira fiel à gravação, entoando novamente os versos:

\section{Muito prazer eu sou Zezé}

Mas você pode me chamar como quiser

Eu tenho fama de ser maluquete

Ninguém me engana nem joga confete

Mas pra quem gosta de amar e segredo

Eu sou um prato cheio

Eu quero dar uma colher, pois é 


\section{Eu sou Zezé \\ Da terra do sol \\ Da lua de mel \\ Da cor do café}

Muito prazer eu sou Zezé

Uma rainha, uma escrava, uma mulher

Uma mistura de raça e cor

Uma vida dura mas cheia de sabor

É que hoje em dia estou mais atrevida

Muito mais sabida

Se não gostar eu dou no pé, pois é

$\mathrm{Na}$ ocasião, Zezé Motta repetiu a intervenção falada que efetua na gravação original, e que visa fornecer à canção o mesmo efeito de verdade que a intervenção de Gal Costa em Meu nome é Gal. Aqui, a cantora diz: "Oi! Eu sou Zezé! Tem gente que me chama de Xica, outros de Zezé... Mas pode me chamar como quiser! (gargalhada)". Embora não tenha repetido esta intervenção ao longo dos mais de 35 anos em que vem interpretando Muito prazerer, Zezé, a artista parece ficar de fato confortável em ser chamada "como seu interlocutor quiser", em termos metafóricos. Isso porque ela aceitou, ao longo do tempo, ser objeto de vários registros biográficos.

A música de Rita Lee foi apenas um dentre os fractais produzidos a respeito da estrela de Xica da Silva. A autobiografia que Zezé Motta narrou para Rodrigo Murat (2005), publicada na Coleção Aplauso, também. Pelo menos outros quatro projetos são dignos de nota: a longa entrevista publicada no livro Damas negras, de Sandra Almada (1995), que lida com o tema da discriminação racial a partir dos relatos com outras três atrizes negras; o Álbum de retratos organizado por Walter Carvalho (2008), que retraça a história pessoal da artista através de fotografias; o filme biográfico La femme enchantée, produzido em 1987 para uma série sobre cultura negra na TV francesa; e a entrevista concedida para mim mesmo dentro do projeto que resultou no livro Solistas dissonantes: História (oral) de cantoras negras (2009).

Parece sugestivo que nada disso tenha sido suficiente para Zezé Motta: apesar de simbolicamente poder ser "chamada como seu interlocutor quiser", não há garantias de que suas aspirações serão satisfeitas. Em 2014, completando 70 anos de idade, ela divulgou uma série de projetos televisivos, cinematográficos e musicais. Além deles, o de uma autobiografia, produzida em colaboração com o escritor cubano Carlos Moore. Ao jornal Estado de Minas, ela disse, sobre as entrevistas gravadas que irão calcar a autobiografia:

Passei noites em claro remoendo aquelas coisas que foram ditas. Para você ter ideia, no segundo encontro, pensei em desistir. É muito dedo na ferida. Ele cutuca mesmo. Porque as biografias que existiam a meu respeito focavam na minha carreira, e essa aborda também a minha vida, desde o momento em que estava no útero da minha mãe. ${ }^{6}$

Feridas como as de Zezé Motta, possibilidades de escolha como as de Cássia Eller, idealismos como o de Gal Costa e conexões coletivas como as de Chico César se amalgamam em Rosa in Blues, obra composta por Roberto Menescal para Rosa Marya Colin, quando ele produzia o LP de mesmo título que a cantora gravou e lançou em 1991. Por muito tempo, Rosa utilizou a música para abrir seus shows: "Só num blues sou feliz porque / só assim sei posso ficar / bem mais perto de você", encerrava. A obra vale a menção, mas merece um estudo à parte - não apenas é prenhe de referências à tocante história de vida da cantora, mas é uma janela para temas atinentes à música feita no Brasil, ao lugar do negro na história dessa música, às relações entre arte e profissionalização - temas que abordei parcialmente em Solistas dissonantes: História (oral) de cantoras negras (2009), do qual Rosa Marya Colin é uma das personagens, mas que merecem uma exploração muito mais verticalizada, passível de ser feita a partir dos versos de Rosa in Blues.

Teremos muita dificuldade em saber quantas canções biográficas jamais foram gravadas pelas personagens perfiladas, por razões óbvias. Supomos e sabemos que elas existem, porém: Alaíde Costa e Rita 


\section{Artigos}

Ribeiro são dois exemplos. A primeira ganhou Desafio de Rodrigo Botter Maio, que se vale de referências à própria linguagem musical para aludir à trajetória de uma artista cuja discrição em relação à sua vida pessoal não impediu que seu público supusesse que esta foi marcada pelo enfrentamento constante de adversidades, com as quais a doçura e a singeleza do canto e do jeito de ser da artista contrastam. "Minha vida é um desafio / Cheio de saltos, incertezas / Vivo em busca da harmonia / São meus acordes de defesa", escreveu Botter Maio, na estrofe que abre a canção, para no refrão concluir: "Com toda essa delicadeza que é a minha bossa / Ai que beleza, fiz minha vida pra cantar" (Santhiago, 2013, p. 15).?

Ainda que Alaíde Costa não a tenha gravado, trazendo para si o seu enunciado, ela poderia tê-lo feito. Ao narrar sua história de vida para mim, não foram poucos os desafios que ela enumerou: "Família pobre, sem água e luz em casa..." (Santhiago, 2009, p. 243); "negrinha, magrinha, de pernas finas, mal vestida” (p. 248); "minha família não aceitou minha escolha na música" (p. 258); "havia uma certa discriminação em relação à minha postura musical” (p. 259). Eles estão salteados em um relato distenso, nunca marcado pela autocomiseração, mas pela escolha subjetiva de um caminho, o mesmo que Botter Maio identificou em sua canção, aquele que supera "saltos, incertezas": "Vivo pela música que faço e todos sabem disso" (p. 260).

O caso da construção de Itamar Assumpção projetada como autoconstrução sobre Rita Ribeiro é menos calcado em um paralelismo com a vida dela. É verdade que a letra da canção parte de uma asseveração não somente firme e inquestionável, mas que é também uma marca de origem fundamental: "Eu sou do Maranhão". Esta referência geográfica, no entanto, não é acompanhada por outras que seriam clássicas em uma construção autobiográfica. O compositor se satisfaz com o recurso da geografia para criar uma persona cosmopolita, para quem importa acima de tudo cantar, seja "por profissão / tanto quanto por gostar / tanto faz se Japão, United States / Europa / Madagascar". Os gêneros também são múltiplos: "bumba, reggae, baião / céu azul, jazz, chachachá” e "o tango da paixão", em uma variedade ampla que confirma o que se diz, no fim da letra: "casar ainda não / eu só quero namorar” (Assumpção, 2013, p. 25).

Há outros casos especiais. Eu sou Baby Consuelo, Luiz Galvão, Pepeu Gomes e Moraes Moreira, poderia ter servido como a afirmação de uma autoridade artística no momento em que a artista - nascida Bernadete Dinorah de Carvalho Cidade - deixou Os Novos Baianos, grupo em que se consagrou como vocalista, e partiu para carreira solo. A mudança, entretanto, era apenas parcial: um número grande das faixas de seu disco de 1978, O que vier eu traço, tinha a participação dos membros do grupo. A canção bradava:

Eu quero é peles, panos

Cores mis

Porque em cima de moi

Só confecções

Porque o corpo mesmo

Está por dentro

Por dentro da pele

E por mais cobertas

Eu sou nua por cima da parede

A rua

E tem mais, eu sou fé em Deus

E pé no mundo

E sem carta e sem selo

Eu vou, eu vou

Eu sou, eu sou

Eu sou Baby Consuelo!

7 A letra está reproduzida em: Santhiago, 2013, p. 15. 
Eu sou Baby Consuelo!

Eu sou Baby!

Baby Consuelo!

Além da escassez de referências biográficas ou de personalidade, outro elemento pode ter se apresentado como entrave para a conexão próxima entre a canção e a imagem de Baby: a vulgarização excessiva de sua persona na circunscrição da canção. Ainda era dos Novos Baianos, havia Baby Consuelo, que pouco dizia além de repetir: "Baby Consuelo sim, por que não?" e "Baby Consuelo é o ponto, é o traço". Na carreira solo, em Samba Fenomenal, Fausto Nilo e Moraes Moreira falavam "Es mi Consuelo Boneca". Então, a que Baby ou a que Consuelo deveríamos nos referir para além do seu nome, e nada mais?

Essa insistência nos nomes, aliás, é curiosa. É significativa por se tratar da necessidade de afirmação de um nome artístico acima de um nome de batismo, que correspondia a uma persona artística (marcada por peles e panos, alusão ao visual e ao estilo de vida hippie característico do grupo Os Novos Baianos) e também a uma essência "por dentro da pele" - mas também porque reforça os questionamentos a respeito do abandono de uma identidade artística a partir dos anos 1990, quando Bernadete deixou de ser "Baby Consuelo" e assumiu o nome artístico "Baby do Brasil", depois de uma peregrinação a Santiago de Compostela. Depois disso, a artista seguiu caminhos cada vez mais esotéricos. É difícil não lembrar, ainda, que a temática dos nomes ficou associada a Baby de maneira pitoresca: ela deu a seus filhos os singulares nomes Riroca (com vibrante das duas letras R), Zabelê, Nãna Shara, Pedro Baby, Kryshna Baby e Kriptus Baby. O insólito não se atenuou quando Riroca decidiu trocar seu nome, incomodada porque os outros o achavam diferente demais: afinal, o novo nome escolhido foi Sarah Sheeva. Tudo isso motivou, a título de deboche, a criação de um aplicativo na Internet, chamado "Gerador de nomes de filhos da Baby Consuelo".

Sem o mesmo estardalhaço de, e sobre, Baby Consuelo, algo semelhante ocorreu no que diz respeito à ênfase no nome próprio em um número grande de composições musicais: foi a cantora de cirandas pernambucana Lia de Itamaracá quem mereceu várias músicas em sua alusão. Desde que Teca Calazans disse que "esta ciranda quem me deu foi Lia”, Paulinho da Viola escreveu Eu sou Lia; Paulo Fernando Ferreira fez Ciranda de Lia; Fernando Borges e Ozires, Chamego de Lia; José Gonçalves Ramos compôs Lia é Lia; Baracho, Quem me deu foi Lia; e Neres e Saúde, Preta cirandeira, que diz: “Eu perguntei: 'quem é essa negra?' / Sou Lia de Itamaracá”. Não temos dúvidas de que ela é Lia - mas quando as construções biográficas são tantas, podemos até pensar duas vezes.

\section{A arte da felicidade}

Um caso comparativo mais viável é aquele que envolve Maria Alcina, a artista singular que mobilizou o Brasil interpretando Filho maravilha no VII Festival Internacional da Canção, em 1972, a quem é impossível ficar indiferente. Não à toa ela foi assunto e intérprete de duas canções autobiográficas. A cantora desde sempre encarnou a performer como poucos sabem fazer, muitas vezes em canções provocativas que valorizaram sua figura excêntrica e transgressora. "Disseram que eu era / Escandalosa!", gravou, de Moacyr Silva e Djalma Esteves, em 1979. Dois anos depois, emendou, de Jorge Alfredo e Chico Evangelista: "Eu sou doida, bonita e gostosa / Eu sou doida / (...) Mas não pense que eu sou boba”.

O caso de Maria Alcina é ilustrativo do alcance e dos limites da construção do eu/outro na canção. No ano de 2009, depois de vários trabalhos que haviam trazido a cantora de volta à cena e a alçado a uma categoria de prestígio distinta da que ela havia ocupado nas décadas de 1980 e 1990 - quando estava, se não longe dos holofotes, relegada a um nicho popularesco, tido como brega ou passadista na percepção da audiência -, a cantora lançou um novo CD. Anos antes, com o grupo de música eletrônica Bojo, ela já havia feito Agora (2003), elogiado pela crítica especializada e determinante para a revalorização e redirecionamento de sua carreira. Mas Maria Alcina Confete e Serpentina (2009) é que efetivou seu retorno como solista ao mercado fonográfico.

Desde seu título, o disco esteve marcado pela compatibilização cuidadosa que Maria Alcina soube e teve de operar entre dois conjuntos simbólicos. De um lado, sua persona pública excêntrica, extremamente caris-

8 http://virgula.uol.com.br/musica/pop/gerador-de-nomes-de-filhos-da-baby-do-brasil-vira-meme-veja-qual-e-o-seu 


\section{Artigos}

mática, espontânea e desinibida, associada a símbolos de uma brasilidade estereotipada, como a sensualidade (ora escancarada, ora insinuada), o bom humor e a alegria carnavalesca. De outro lado, o compromisso com a tradição da melhor música popular-comercial feita no Brasil, em um corte transversal que comporta sua própria renovação e que rejeita o primado do prestígio social sobre as qualidades estéticas e comunicativas da obra de arte. Maria Alcina Confete e Serpentina foi, de certa forma, emblema dessa negociação complexa que se derrama sobre toda a carreira recente da artista.

Ocorre que, dentre as faixas do disco, existe uma em especial: a que lhe dá título. Inspirada em uma marchinha, a canção de Adalberto Rabelo Filho, compositor que criou bandas como Numismata e Judas, traceja um personagem ambientado no carnaval. É "Maria Alcina / confete e serpentina / vison, lamê, brilho / pluma e paetê", e também "papel machê / canutilho e purpurina". Fortemente cativante, a música não se esgota no refrão e na rima. Ela convida a uma entrega total à dança, ao abandono da "vã filosofia", ao esquivo da "apatia" e da "falta de alegria": importa o corpo, apenas, no "balançar" do "esqueleto" ou na inoculação de uma "nova epidemia".

A epidemia de que se fala pressupõe algum tipo de contato corporal, e ele é performatizado na última estrofe da canção: "misturar minha miçanga / no seu corselê / na minha coreografia / tem seu pas-de-deux". Além de falar em mistura, de levantar hipóteses sobre o absorvimento de contas coloridas por uma peça de roupa, de aludir a um passo de dança executado em duo, o trecho realiza linguisticamente esse contato, valendo-se pela primeira vez de um apelo direto ao interlocutor. Os versos finais, no entanto, despersonificam esse interlocutor. O comportamento algo invasivo de propor (e efetivar) a mistura ondulante dos corpos na busca da alegria é justificado com base na psicologia social: "porque alguém tem que fazer / o que é preciso / e invadir / o inconsciente coletivo". Assim como em Meu nome é Gal, fala-se portanto de Maria Alcina para falar de algo mais amplo. Fala-se da predisposição mais do que para a alegria, para a festa, para a dança, para os confetes e as ondulantes serpentinas, para coloridas vestimentas femininas - para o desbunde, para o júbilo pós-tropicalista do qual a cantora é símbolo alto.

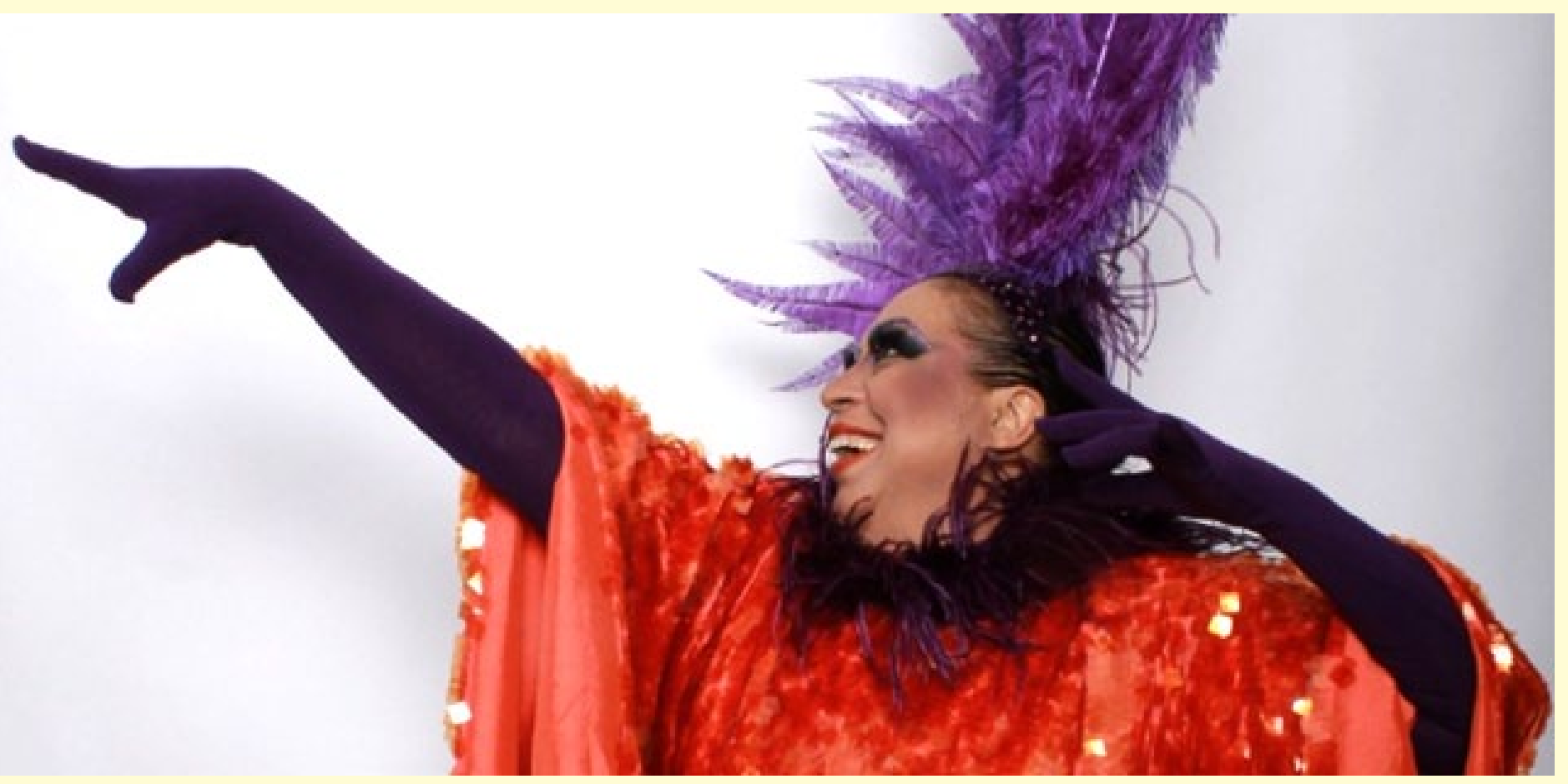

Essa ênfase no "inconsciente coletivo" talvez ajude a explicar porque, cinco anos depois, os ouvintes da cantora mineira sejam apresentados a uma nova perspectiva autobiográfica, que muito conscientemente faz uma travessia para o plano individual - embora não seja o caso de se falar em um projeto de complementaridade. Essa segunda construção fez parte do álbum De normal bastam os outros, que novamente extremou os elementos (visuais, performáticos, etc.) inusitados de Maria Alcina. A faixa-título, composição de Arnaldo Antunes, tem seu significado engrandecido quando aposto sobre a cantora: "De normal bastam outros / Para mim é muito pouco / Começou um novo tempo", ela canta a certa altura, numa linearidade excepcional dentro de uma letra que no mais é surreal. Interessa, entretanto, a música que abre o disco: "Eu sou Alcina”, de Zeca Baleiro. 
"Eu sou Alcina" é um título poderoso. Em primeiro lugar, é assertivo e, pode-se dizer, é também tautológico, o que reforça sua assertividade. Além disso é conciso, pois reúne as atenções do leitor ou ouvinte em um único nome, o nome próprio Alcina. É um título poderoso, ainda, porque fala em "Alcina", não em "Maria Alcina" - proporcionando a imersão do ouvinte em um círculo íntimo, sugerindo banhá-lo com uma representação do que há de mais privado sobre a artista, despida agora de seu nome composto, como de seus confetes e serpentinas. Sob isso tudo, porém, que segredos encontramos?

Uma canção extremamente alegre, cuja letra realiza a construção biográfica a que se propõe principalmente a partir da reiteração de qualificativos que indicam a faceirice e a afabilidade de Maria Alcina, que se narra como "sapeca", "moleca", "menina", “altiva”, “ativa”, "montada", "ladina”, e assim por diante; como alguém fácil de lidar, um "doce de mulher"; como alguém disposto a atender os desejos demais, porque "canto samba para quem sambar"; como alguém eclético, porque "canto rumba, canto rock e cha-cha-cha"; como alguém autêntico, porque "sento na praça na hora do rush / ando de avião mas prefiro ir a pé". Diante de suas plumas e paetês, de seus confetes e serpentinas, de sua simpatia no palco e fora dele, seria difícil desafiar essa construção. A última estrofe, entretanto, pode ser desconcertante:
Ninguém me tira se eu tô na roda
Eu nunca saí de moda
Só quero quem bem me quer
Eu sempre fui mesmo da pá virada
Safada fada fadada
A ser o que sou, pois é

Não é difícil acreditar que a Maria Alcina personagem seja efetivamente da "pá virada" sendo também o "doce de mulher" e o "mamão com açúcar" do resto da canção". A transição operada na última estrofe capta um pouco da complexidade da vida, rara em outras canções biográficas, e pode ter inúmeras camadas de sentido. "Ninguém me tira" pode ser a informação mera e simples do apego à dança - mas pode ser a queixa de quem não é convidada a dançar por mim tanto quanto a orgulhosa declaração de quem não é desafiada, na linguagem popular. "Nunca saí de moda” é a reelaboração idealizada do passado, mesmo a negação do passado recente - mas isso se dá de forma intencional ou involuntária, e por quê?

A canção, entretanto, não resolve dilemas - tão somente sinaliza, com muita discrição, porque precisa atender as expectativas de seus ouvintes. É até aí que a rima de "eu sempre fui mesmo da pá virada" nos leva. "Safada fada fadada / a ser o que sou, pois é", e a canção se repete: "Eu sou Alcina...". Esses versos finais determinam: nas filas, vilas, favelas; aqui, ali, em qualquer lugar, Maria Alcina está condenada a ser tão alegre quanto a canção que canta, fadada a ser "uma sapeca, uma moleca, uma menina". Então, no limite, Maria Alcina Confete e Serpentina e Eu sou Alcina não são tão diferentes assim: "alguém tem que fazer o preciso", diz a primeira; "fadada a ser o que sou", diz a segunda. Nenhuma concede à cantora-personagem alternativa: a alegria é inevitável.

A repercussão do disco De normal bastam os outros levou sua intérprete ao programa de entrevista sui generis conduzido por Antonio Abujamra na TV Cultura, o Provocações. A certa altura, Abujamra perguntou a Alcina: "Cantar fados, tangos, polcas, sambas e modinhas - tudo isso você fazia. E isso te curava os males da alma?". Sem hesitar, ela respondeu: "A música realmente consegue dar essa cura". E o apresentador devolveu-lhe uma pergunta menos confortável: "Então fala pra nós quais são os seus males da alma". Desta vez, Maria Alcina pestanejou, mas encontrou uma forma de responder:

\footnotetext{
Ah, aí o bicho pega, Abujamra... [gargalhada] Eu tô sempre rindo, eu tô sempre assim, né? "Ai, ela é tão pra cima, ela é tão...” Não é bem assim. Isso pra mim foi um jeito de eu me defender, também, sabe, Abujamra? Porque chega uma hora que a gente tem muito sucesso, depois você não tem mais. E quando você está aqui no limbo, tudo fica mais fechado. Então eu pensei: hummm, como é que eu vou driblar isso aí? Sorrindo. Sorrindo aqui na cara e dentro, por dentro. Eu chegava e: “Ahn!” [corrige a postura, sugerindo a mudança automática diante de uma nova situação]. É quase uma arma. Entendeu? É isso aí pra curar meus males."
}

9 Provocações 676 com a cantora Maria Alcina - bloco 02. Disponível em: https://www.youtube.com/watch?v=rFwsKMdfVjQ. 
Artigos

A artista fala com maior facilidade de seus "males da alma" em comparação a como fazia 11 anos antes, em 2003, em uma longa entrevista de história de vida para o site Gafieiras. Na ocasião, ela foi desafiada em um único momento a confrontar possíveis mágoas, e desviou da questão de maneira menos astuciosa, evitando falar sobre ela e, diante da insistência do entrevistador, mudando de assunto de maneira categórica, declarativa:

Tacioli - Depois do festival e do primeiro disco, você tinha claro uma linha pra sua carreira?

Maria Alcina - Não, você pode ver que quando conto sobre alguma coisa que aconteceu é porque aconteceu! [risos] Aconteceu! Nada programado.

Tacioli - Mas esse 'aconteceu' em algum momento lhe chateou?

Maria Alcina - Nunca, somente veio coisa boa. E as coisas ruins deixo no armário lá de casa. Minha irmã que falava assim... "Pega o bicho, guarda-o dentro do armário e deixa lá!" [risos] Adoro essa coisa que minha irmã falou. [ri] Aprendi a lidar com o positivo. O negativo deixo em casa.

Tacioli - E não há mágoas?

Maria Alcina - Que tem, tem, mas eu esqueço! [risos] É verdade. Ultimamente não reclamo mais nem com os amigos. Tô aprendendo a... "Ninguém presta atenção! [risos] Vou ficar falando sozinha? Não sou louca!" [risos] Ainda não. Mas voltando, acho que a única parte programada que teve na minha carreira foi com o Mauro Furtado na Number One.

Talvez porque naquele período seu novo lugar no cenário musical, como cantora "cult", não estivesse consolidado, a cantora não se sentisse suficientemente segura para abordar o mal da alma que revelou a Antonio Abujamra: as tristezas decorrentes do confronto com o malogro, com as incertezas. Ela ainda não havia desenvolvido os meios para lidar com seus conflitos internos, precisando ainda de um tempo maior para fazê-lo. A alegria do palco precisava transbordar para muito além dele. Como cantou Amália Rodrigues, em O fado da Adiça: "Soa a guitarra cantando / a alegria que fingimos / o fado que nos cantamos / é sina que nos cumprimos".

As narrativas pessoais de Maria Alcina, oferecidas em duas circunstâncias bastante diferentes, mas ambas cercadas por um aparato tecnológico bastante evidente, não podem ser chamadas de confissões íntimas. Ainda assim, oferecem insights para a personalidade do ser humano para além de sua obra; para a história das emoções da artista abaixo da história de suas criações. Por pequenos que sejam, trechos de suas entrevistas sinalizam para as dificuldades de lidar com expectativas e condições concretas, para os processos de decisão encaminhados em situações limite, para acontecimentos biográficos entendidos como divisores de água.

As canções biográficas em princípio devotadas a canalizar a volatilidade da essência do artista, entretanto, fraquejam. Será que a música é um espaço pouco propício para representar conflitos? Será que seria impossível fazer uma canção autobiográfica que pelo menos dedilhasse a complexidade e as contradições de um indivíduo? Certamente não. A limitação não parece estar na forma, dado que a canção tem sido um lugar privilegiado para a discussão de temas que vão da esfera confessional à social, ao plano político/ideológico - a dificuldade está na apreensão e na tradução de uma essência humana em palavras, se assim quiséssemos dizer.

Cabe, aliás, lembrar que Maria Alcina esteve colateralmente envolvida em um conhecido episódio envolvendo a representação biográfica na forma de canção. A cantora consagrou-se como intérprete da música vencedora da fase nacional do VII Festival Internacional da Canção, promovido pela TV Globo: Fio Maravilha, de Jorge Ben. Trata-se de uma canção feita por Jorge Ben em homenagem a João Batista de Sales, atacante do Flamengo conhecido pelo apelido de Fio Crioulo-doido, que não alcançou grande notoriedade, mas chamou a atenção do compositor, por sua capacidade de realizar gols com muita criatividade, como ele descreve em sua empolgante canção. ${ }^{10}$ À época, Fio foi à Justiça para cobrar parte dos direitos autorais pelo uso de seu nome e imagem - em um processo desgastante que obrigou Jorge Ben a alterar o nome e a letra da música para Filho Maravilha, em um episódio que antecipou questões recuperadas em 2013, em importantes debates públicos acerca da representação biográfica.

Se formos adiante com as "canções de não-ficção" escritas sobre personagens - como as chamou Paulo César Araújo (2013) - encontraremos Alô, Alô, Taí, Carmem Miranda, samba enredo da Império Serra-

10 Ver: Severiano \& Mello, 1998. 
no, do ano de 1972; Brigitte Bardot e Giulietta Masina, observadas por Tom Zé e Caetano Veloso, respectivamente; Helô Pinheiro, transformada na Garota de Ipanema de Tom Jobim e Vinicius de Moraes; Carlos Gardel e Francisco Alves, vertidos em um tango e um samba compostos em parceria por Herivelto Martins e David Nasser a título de homenagens póstumas. E não saberemos, é claro, o nome de tantas musas e musos reais nada ficcionais que inspiraram e são descritos em muitas das canções que ouvimos e cantamos.

\section{Canta-me}

Canções como essas músicas são homenagens - mas não deixam de ser, em certa medida, uma invasão na vida íntima dos biografados. Em casos como o de Filho/Fio Maravilha, esse acometimento na representação pessoal pode ser contestado. Mais comum é que os biografados/autobiografados o aceitem, cientes de seu uso estratégico na otimização de sua imagem pública, já que pelo menos parte de seus públicos presumidamente tem interesse em suas vidas pessoais.

No âmbito "artístico" frequentado por “celebridades”, o uso da canção autobiográfica como plano para angariar mais "fãs" é eloquente. Veja-se o caso da cantora Sandy, de Sandy \& Junior, após o término da dupla infanto-juvenil que compunha com seu irmão. Depois de ver sua carreira solo fracassar e sua popularidade e seu apelo midiático desmoronarem, ela escolheu uma música declaradamente "autobiográfica" para um disco que sucedeu seu malogrado CD de estreia, Manuscrito, de 2010. Dois anos depois, ela lançou o EP Princípios, meios e fins, cuja canção de trabalho intitulava-se "Aquela dos 30", que falava de sua experiência de estar próxima dos 30 anos, que ela completaria três meses após o lançamento oficial do álbum. Logo ela, que, como toda celebridade que se preze, prefere não falar da "vida pessoal"...

Da vida pessoal tem falado tantos outros, não em canções autobiográficas, mas em uma outra linhagem que conecta canto e vida: aquelas famosas e amplamente populares canções confessionais de centenas de cantores/compositores cujas vidas públicas nos convidam incessantemente a buscar um paralelo em suas obras. Assim tem sido, de Maysa a Alanis Morissette; de Marina Lima a Pink; de Cazuza a Bob Dylan; de Roberto Carlos a Amy Winehouse. Isso sem falar dos rappers e dos antigos sambistas - a maior parte de suas letras se apoia efetivamente em vivências cotidianas. Da etérea descrição feita por Dolly Parton de sua pobre mãe costurando um casaco de retalhos em Coat of Many Colors à caótica revelação pública de sua bissexualidade feita por Renato Russo em Meninos e meninas, cantores que escrevem seus próprios repertórios têm invariavelmente usado a música como extensão de um diário íntimo, principalmente para a expressão de suas angústias. Recentemente, li em um algum blog um comentário sobre o CD mais recente de Shakira, que leva seu nome, de 2014: o argumento era o de que "Shakira não é mais Shakira": estando feliz e completa, casada e com filhos, realizada pessoal e profissionalmente, ela não teria mais grandes aflições pessoais a exteriorizar como havia feito antes em canções como Poem To A Horse (dela e Luis F. Ochoa) ou Costume Makes The Clown (dela e Brendan Buckley). Sem a verve confessional que a havia consagrado, ela estaria condenada ao fracasso, sugeria ao blog, em uma sugestiva equivalência entre a disposição autobiográfica e a predisposição ao sucesso.

Os artistas sabem muito o que fazem ao cantar-se autobiograficamente, de maneira mais ou menos explícita, com palavras de sua lavra ou pela aceitação da montagem de outrem. Eles conhecem bem a gama de consequências a que a boa ou má escolha do repertório pode levar. Então, por que escolhem cantar essas canções? Que lugar elas têm no interior de suas obras?

As canções autobiográficas somam-se às entrevistas, às declarações públicas, ao modo de se portar dentro e fora do palco, aos trajes escolhidos, aos cortes de cabelo e penteados cultivados, na definição (e na frequente redefinição) de uma persona pública. Elas se juntam a um grande repertório de afirmações sobre o eu que têm peso importante para a percepção pública sobre a vida e a obra de um artista, mas com uma força dupla, já que são feitas da mesma matéria que sua arte - elemento que cativa o público e que justifica a existência mesma dos demais elementos. Registradas em fonogramas, incluídas em álbuns, são fadadas à longevidade e pouco propensas à modificação; são solicitadas e reapresentadas em shows, com a vênia usual às palavras tais quais foram compostas. Daí que serão sempre livres as Gals, alegres as Alcinas, maluquetes as Zezés - a menos que, na atualização de suas autobiografias cantadas, a palavra seja entendida como uma dentre as partes da canção e curve-se à música, à performance, outros meios de contar histórias. 
Artigos

\section{Referências bibliográficas:}

Almada, S. Damas negras: Sucesso, lutas, discriminação. Rio de Janeiro: Mauad, 1995.

Amaral, B. H. R. Cássia Eller: Canção na voz do fogo. São Paulo: Escrituras, 2002.

Araújo, P. C. "Lei Fio Maravilha”. Folha de S. Paulo, Opinião, 19 de outubro de 2013.

Assumpção, I. Itamar Assumpção: Cadernos Inéditos. São Paulo: Itaú Cultural / Terceiro Nome, 2013.

Boyd, B. On the Origin of Stories: Evolution, Cognition, Fiction. Cambridge: Harvard University Press, 2009.

Bruner, J. Fabricando histórias: Direito, literatura, vida [2002]. São Paulo: Letra e Voz, 2014.

Carvalho, W. Álbum de retratos: Zezé Motta. Rio de Janeiro: Memória Visual, 2008.

Eakin, P. J. Living Autobiographically: How We Create Identity in Narrative. Ithaca: Cornell University Press, 2008.

Genette, G. Narrative Discourse Revisited. Ithaca: Cornell University Press, 1990.

Lejeune, P. O pacto autobiográfico: De Rousseau à Internet. Belo Horizonte: Ed. UFMG, 2008.

Murat, R. Zezé Motta: Muito prazer. São Paulo: Imprensa Oficial, 2005.

Santhiago, R. "A discreta essencialidade de Tata Fernandes". In: VV. AA. Narrativas e experiências: Histórias orais de mulheres brasileiras. São Paulo: D’Escrever, 2009. p. 75-105.

Santhiago, R. Alaíde Costa: Faria tudo de novo. São Paulo: Imprensa Oficial, 2013.

Santhiago, R. Solistas dissonantes: História (oral) de cantoras negras. São Paulo: Letra e Voz, 2009.

Severiano, J.; Mello, Z. H. A canção no tempo: 85 anos de músicas brasileiras - Vol. 2: 1958-1985. $5^{a}$ ed. São Paulo: Ed. 34, 1998. 